\title{
Influence of Sulphur and Spacing on Growth and Yield Attributes of Knol-Khol (Brassica oleracea Var. Gongylodes L.) Var. Early White Viana
}

\author{
R.K. Bairwa ${ }^{1}$, S.P. Singh ${ }^{1}$, A.K. Mahawar ${ }^{1}$ and Kishore Kumar Das ${ }^{2}$ \\ ${ }^{1}$ Department of Horticulture, S.K.N. College of Agriculture, Jobner-303 329, \\ Jaipur, Rajasthan, India \\ ${ }^{2}$ Swami Keshwanand Rajasthan Agriculture University, Bikaner- 334006, Rajasthan, India \\ *Corresponding author
}

\begin{tabular}{|c|c|}
\hline & A B S T R A C T \\
\hline & \multirow{6}{*}{ 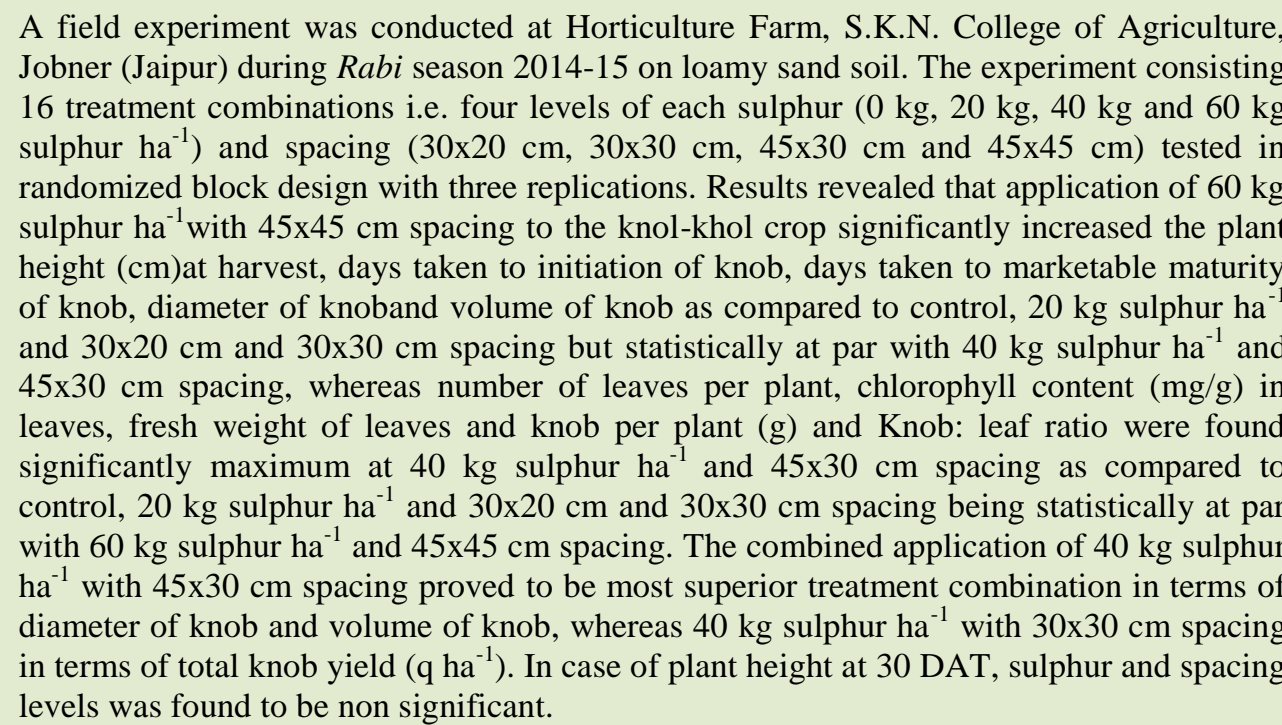 } \\
\hline Keywords & \\
\hline $\begin{array}{l}\text { Sulphur, } \\
\text { Spacing, } \\
\text { Knol-khol, } \\
\text { Growth yield and } \\
\text { interaction effect. }\end{array}$ & \\
\hline Article Info & \\
\hline $\begin{array}{l}\text { Accepted: } \\
25 \text { April } 2017 \\
\text { Available Online: } \\
10 \text { May } 2017\end{array}$ & \\
\hline & \\
\hline
\end{tabular}

\section{Introduction}

In India, the cultivation of knol-khol is popular in Kashmir, West Bengal and some parts of South India. Knol-khol (Brassica oleracea var. gongylodes) is a winter season crop and is originated from the coastal countries of Mediterranean region (Choudhary, 1967). It is commonly grown in Northern India and also in some parts of Rajasthan. The stem swells and stores edible food material specially starch and sugars. When consumed as raw it gives sweetish taste with slight aroma. The stem develops entirely above ground, which is edible and vary delicate in flavour and texture (Singh, 1989). Knol-khol is characterized by formation of knob (tuber) which arises from thickening of the stem tissue above the cotyledon. The formation of knob is best seen at the temperature range of $15-180 \mathrm{c}$. The fleshy turnip like enlargement develops entirely above the ground. The knob is harvested for human consumption either as raw or cooked. 
When eaten raw it gives sweetish taste with slight aroma. It is also utilized for making salad and pickles. Occasionally young leaves are also cooked as vegetable. It is well documented that growth and quality of plants are greatly influenced by a wide range of nutrients. Sulphur is an essential plant nutrient and plays a vital role in biosynthesis of certain amino acids (Cysteine, cystine and methionine) and also helps in the synthesis of co-enzyme-A and formation of chlorophyll and nitrogenase enzyme.

Sulphur is reported from two natural growth regulators viz., thiamine and biotin. Sulphur occurs in glutathione that is important to oxidation reduction reaction (Kanwar, 1976). It is one of the constituents of vitamin B1, some volatile oils and amino acids like methinine $(21 \% \mathrm{~S})$. It is involved in various metabolic and enzymatic processes in the plant (Goswami, 1988). Most of the soils of Rajasthan are alkaline in nature and characterized by high $\mathrm{pH}$ values, which ranges between 8.0-10.0, while, the $\mathrm{pH}$ of the soils of present experiment was 8.2. At this $\mathrm{pH}$ value, the availability of plant nutrients is very low so sulphur fertilization might prove to be beneficial as it brings the soil $\mathrm{pH}$ low.

Keeping adequate plant population per unit area, Knol-khol is most important for its better growth and higher yield. The influenced of spacing on growth, size of knob, days to maturity and yield of Knol-khol under different agro-climatic condition have been reported by various workers.

The spacing of crop may be varied according to climatic condition, soil fertility and cultivars adaptation to particular region. Under the wider spacing, the plant was more vigorous in terms of leaf size, which might be due to less competition for light, nutrients and moisture as compared' to closer spacing (Rai et al., 2003).

\section{Materials and Methods}

The experiment was laid out at Horticulture farm, S.K.N. College of Agriculture, Jobner, Distict Jaipur (Rajasthan) during Rabi season 2014-15. The climate of Jobner is typically semi-arid characterized by extremes of temperature both in summer and winter, low rainfall and moderate relative humidity. Maximum temperature in summer ranges between 30 to $48^{\circ} \mathrm{C}$ whereas, in winter, temperature falls down to as low as $-1{ }^{0} \mathrm{C}$. The average rainfall varies between 250 to 500 $\mathrm{mm}$. The crop was transplanted on $18 / 10 / 2014$ and harvested as last picking on $12 / 12 / 2014$. The mean daily temperature maximum and minimum during the growing season of knol-khol fluctuated 35.0 and $2.0^{\circ} \mathrm{C}$, relative humidity ranged from 52 to 70 per cent. The soil was loamy sand in texture, slightly alkaline in reaction, poor in organic carbon $(0.15 \%)$ with low available nitrogen (128 kg ha $\left.{ }^{-1}\right)$, phosphorus (16.63 $\left.\mathrm{kg} \mathrm{ha}^{-1}\right)$ and sulphur $\left(8.40 \mathrm{mg} \mathrm{kg} \mathrm{kg}^{-1}\right.$ ) and medium in potassium content $\left(154.1 \mathrm{~kg} \mathrm{ha}{ }^{-1}\right)$. The experiment was comprised of 16 treatment combination will be carried out in Randomized Block Design (RBD) with four levels of each Sulphur (0, 20, 40 and $60 \mathrm{~kg}$ $\left.\mathrm{ha}^{-1}\right)$ and spacing $(30 \times 20,30 \times 30,45 \times 30$ and $45 \times 45 \mathrm{~cm})$. Two raised nursery beds of dimensions of $3 \mathrm{~m} \times 1 \mathrm{~m} \times 0.15 \mathrm{~m}$ (Length $\mathrm{x}$ Width $x$ Height) were prepared by mixing well rotten FYM in soil @ $15 \mathrm{~kg} \mathrm{~m}^{-2}$. Seeds of knol-kholcv. Early White Vienna obtained from National Seed Corporation was treated with 0.02 percent thiram to save the seedlings from damping off disease.

\section{Treatment application}

\section{Sulphur}

Sulphur was applied as per treatment through agriculture grade elemental sulphur and was broadcasted uniformly before transplanting 
and incorporated in the soil. The agricultural grade of elemental sulphur (100\% S) was applied as per treatment before 20 days of transplanting.

\section{Spacing}

Sowing of the seedlings was carried out as per the scheduled levels of spacing viz. 30x20 $\mathrm{cm}, 30 \times 30 \mathrm{~cm}, 45 \times 30 \mathrm{~cm}$ and $45 \times 45 \mathrm{~cm}$.

\section{Transplanting}

Five weeks old seedlings were transplanted on 18th October 2014, when average height of seedlings was about $5-7 \mathrm{~cm}$. The distance between row to row and plant to plant was kept at four levels of spacing $(30 \times 20,30 \times 30$, $45 \times 30$ and $45 \times 45 \mathrm{~cm}$ ).

\section{Characters studied and observations recorded}

\section{Growth parameters}

Plant height $(\mathrm{cm})$, Number of leaves per plant, Total chlorophyll content in leaves $(\mathrm{mg} / \mathrm{g})$, Days taken to initiation of knob and Days taken to marketable maturity of knob.

The amount of total chlorophyll was calculated as advocated by Arnon (1949).

Total chlorophyll $(\mathrm{mg} / \mathrm{g})=$

A (652) X 29 X Total volume (ml)

$\alpha$ X 1000 X Weight of sample (g)

Where,

A = Absorbance specific wave lengths

$\alpha$ is the path length $=1 \mathrm{~cm}$

\section{Yield and yield attributes}

Diameter of knob (cm), Volume of knob (cc), Knob: leaf ratio and Total yield of knob $\left(\mathrm{q} \mathrm{ha}^{-1}\right)$.

\section{Results and Discussion}

\section{Effect of sulphur on growth attributes}

It is apparent from data (Table 1) that varying sulphur levels influenced the plant height significantly. Application of $60 \mathrm{~kg}$ sulphur recorded the maximum plant height $(30.40$ $\mathrm{cm})$ at harvest and proved superior to control and $20 \mathrm{~kg}$ sulphur with 18.06 and 6.85 per cent higher at harvest, respectively. Application of $60 \mathrm{~kg}$ sulphur was found to be statistically at par with $40 \mathrm{~kg}$ sulphur per ha. The difference in plant height at 30 DAT due to application of $60 \mathrm{~kg}, 40 \mathrm{~kg}$ and $20 \mathrm{~kg}$ sulphur were found non-significant to each other. Due to sulphur fertilization, xylem and collenchymas fibre are also reported to be thickened resulting into more pronounced growth of plant (Biswas et al., 1995). Increasing vegetative growth of knol-khol due to sulphur fertilization in the present investigation are in close conformity with the finding of Yadav and Paliwal (1990), Sekhawat (1992), Dhar et al., (1999) and Bhagavatagoudra and Rokhade (2001).

Increasing levels of sulphur application to knol-khol recorded maximum number of leaves per plant and total chlorophyll content in leaves with $60 \mathrm{~kg}$ sulphur. Application of $40 \mathrm{~kg}$ sulphur being at par with $60 \mathrm{~kg}$ sulphur proved significantly superior indicated an increase of $29.65,9.57$ and $22.58,8.57$ per cent in number of leaves per plant and chlorophyll content in leaves over control and $20 \mathrm{~kg}$ sulphur, respectively. It is obvious because of the fact that the application of sulphur has been reported to improve not only the availability of the sulphur but of other nutrients too, as sulphur results in lowering the soil pH (Hossan and Olsen, 1966). It also plays an important role in energy transformation, activation of a number of enzymes, carbohydrate metabolism and chlorophyll formation. The present 
investigations are in close conformity with the finding of Nagda (1970), Yadav (1990), and Bhagavatagoudra and Rokhade (2001).

Sulphur also plays an important role in the production of chlorophyll. It was found that the sulphur increased the chemical and biological activation of iron in the leaves resulting in increased chlorophyll content, Ergle and Eaton (1951), Singh et al., (1988), Biswas et al., (1995) and Chhipa (2005).

Data presented in same table also revealed that application of different sulphur levels significantly affected the days taken to initiation of knob and days taken to marketable maturity of knob. The right time knob initiation was recorded with the application of $40 \mathrm{~kg}$ sulphur (29.07 days and 52.66 days) and $60 \mathrm{~kg}$ sulphur (28.77 days and 50.85 days) which were found statistically at par to each other. Although the initiation of knob and marketable maturity of kno under control and $20 \mathrm{~kg}$ sulphur were induced later.

The days taken to initiation of knob and marketable maturity of knob reduced significantly due to sulphur fertilization, whereas the highest level of sulphur brought about highly significant reduction in days taken to initiation of knob and marketable maturity of knob in comparison to control. This was perhaps due to a vital role of sulphur in the activation of a number of enzymes and also in carbohydrate metabolism in plant, thus may have provided proper inter plant balance thereby enhancing early maturity and initiation of knob (Tandon, 1986) which in turn might have favoured better knob formation and development and resulted in increased growth and ultimately higher yield.

The results are in close conformity with those of Meena (2004), Jamre et al., (2010) and Gautam (2012).

\section{Effect of sulphur on yield attributes}

A perusal of data (Table 1) showed that application of sulphur levels had significant effect on diameter of knob and volume of knob. Maximum diameter and volume of knob $(7.75 \mathrm{~cm}$ and $115.92 \mathrm{cc})$ was recorded in $\mathrm{S}_{3}$ treatment (60 kg sulphur per ha), while minimum diameter and volume of knob (6.27 $\mathrm{cm}$ and $98.80 \mathrm{cc}$ ) was recorded in $\mathrm{S}_{0}$ (control) treatment. Application of sulphur up to $60 \mathrm{~kg}$ per ha being at par with $40 \mathrm{~kg}$ per ha, significantly improved the diameter and volume of knob indicating an increase of 23.60, 10.24 and 17.33, 6.92 per cent over control and $20 \mathrm{~kg}$ sulphur per ha, respectively. The increase in yield and yield attributes might be due to the important role of sulphur in lowering the $\mathrm{pH}$ of saline alkaline soil resulting in increased availability of many nutrients (Hossan and Olsen, 1966) or might to be the activation of a number of enzymes and also in carbohydrate metabolism (Tandon, 1986) which in turn might have favoured better knob formation and development and resulted in increased growth and ultimately higher yield. The results are in close conformity with those of Hara et al., (1981), Bijania and Dixit (1996), Bhagavatagoudra and Rokhade (2001) and Gautam (2012).The fresh weight of leaves and knob, knob: leaf ratio and total yield (q/ha) increased significantly with increasing levels of sulphur. The maximum fresh weight of leaves (156.86 g), knob (133.37 g), knob: leaf ratio (1.18) and total yield (223.64 q/ha) was recorded in $60 \mathrm{~kg}$ sulphur per ha while miminum was recorded in control $(70.35 \mathrm{~g}$, $72.71 \mathrm{~g}, 0.97$ and $156.70 \mathrm{q} / \mathrm{ha})$. Application of $40 \mathrm{~kg}$ sulphur being at par with $60 \mathrm{~kg}$ sulphur gave significantly higher fresh weight of leaves and knob, knob: leaf ratio and total yield indicating an increase of 109.77, 28.85 and $73.72,22.41$ and 20.62, 5.41 and 38.25, 13.15 per cent over control and $20 \mathrm{~kg}$ sulphur, respectively. The increase in yield attributes was probably due to source and sink 
relationship. The increase in yield attributes can be attributed to increase the size of source and consequently the enhanced partitioning of photosynthetes toward sink. The results revealed that application of $60 \mathrm{~kg}$ sulphur per ha significantly increased the knob yields per ha of knol-khol as compared to control and 20 $\mathrm{kg}$ sulphur per ha, which were found statistically at par with $40 \mathrm{~kg}$ sulphur per ha. These finding corroborates with the findings of Sekhawat (1992), Dhar et al., (1999), Jamre et al., (2010), Gautam (2012) and Talukder et al., (2013)

\section{Effect of spacing on growth attributes}

The perusal of data (Table 1) revealed that the plant height at harvest, number of leaves per plant and total chlorophyll content in leaves was significantly affected by various spacings. The maximum plant height at 30 DAT and at harvest $(16.88 \mathrm{~cm}$ and $30.16 \mathrm{~cm})$, number of leaves per plant (9.62) and increase in chlorophyll content $(0.77 \mathrm{mg} / \mathrm{g}) \quad$ was recorded with $45 \times 45 \mathrm{~cm}$ spacing, while minimum was recorded under $30 \times 20 \mathrm{~cm}$ spacing $(16.08 \mathrm{~cm}$ and $26.40 \mathrm{~cm}, 7.55$ and $0.64 \mathrm{mg} / \mathrm{g}$ ). The spacing $45 \times 45 \mathrm{~cm}$ was found superior over $30 \times 20 \mathrm{~cm}$ and $30 \times 30 \mathrm{~cm}$ spacing at these parameters which is statistically at par with $45 \times 30 \mathrm{~cm}$ spacing, respectively, but in case of plant height at 30 DAT, spacing $45 \times 45 \mathrm{~cm}$ were found nonsignificant to other spacing levels.

The close spacing offered severe competition between the plants for nutrients, moisture, light and space due to which tallness in plants was observed. On the other hand at wider spacing plant received more sunlight and more nutrients due to less number of plants which could increase the plant height, number of leaves per plant and chlorophyll content in leaves. The present results are in close aggrement with the findings of Patil et al., (2003), Singh et al., (2004), Prasad et al., (2010), Khatun et al., (2011), Moniruzzaman
(2011), Solunke et al., (2011), Dev (2012), Thirupal et al., (2014), and Mehta et al., (2015). A critical examination of the data (Table 1) revealed that levels of spacing significantly affected days taken to initiation and marketable maturity of knob over 30x20 $\mathrm{cm}$ and $30 \times 30 \mathrm{~cm}$. Spacing $45 \times 45 \mathrm{~cm}(28.81$ days and 51.09 days) registered right time initiation of knob and marketable maturity of knob over $30 \times 20 \mathrm{~cm}$ and $30 \times 30 \mathrm{~cm}$ spacing which is statistically at par with $45 \times 30 \mathrm{~cm}$ spacing (29.51 days and 52.74 days). The delay in initiation and marketable maturity of knob were recorded in $30 \times 20 \mathrm{~cm}$ spacing (34.14 and 57.85 days).The days taken to initiation of knob and marketable maturity of knob reduced significantly under wider spacing. The spacing is important characteristics to know the variation of different parameters performance of a crop.

Proper spacing in knol-khol reduce the days which are require for initiation of knob and marketable maturity of knob and also decrease the percentage of it. Closer spacing reduce more time taken to initiation of knob than wider spacing because closer spacing decrease the maturation of crop by less availability of sunlight, fertilization space and more activity of tissues in a given area. The right time maturity was observed in closest spacing. In wider spacing, plants have to take more time to complete their physical and biological activities due to more availability of space, sunlight and fertilization. When the time taken to initiation of knob is reduced the days taken to marketable maturity is also reduced in closer spacing. These results are in close conformity with the findings of Patil et al., (2003) in knol-khol, Khan et al., (1991), Bhangre et al., (2011), Dev (2012) and Thirupal et al., (2014) in broccoli who reported that close spacing reduced the days to knob initiation, head initiation, flower bud initiation, maturity and harvest duration of crop. 
Table.1 Effect of sulphur and spacing on growth attributes of knol-khol

\begin{tabular}{|c|c|c|c|c|c|c|}
\hline \multirow[t]{2}{*}{ Treatments } & \multicolumn{2}{|c|}{ Plant height } & \multirow[t]{2}{*}{$\begin{array}{c}\text { Number of leaves } \\
\text { per plant }\end{array}$} & \multirow[t]{2}{*}{$\begin{array}{l}\text { Chlorophyll } \\
\text { content }\end{array}$} & \multirow[t]{2}{*}{$\begin{array}{c}\text { Days taken to } \\
\text { initiation of knob }\end{array}$} & \multirow[t]{2}{*}{$\begin{array}{c}\text { Marketable } \\
\text { maturity of knob }\end{array}$} \\
\hline & At 30 DAT & At harvest & & & & \\
\hline \multicolumn{7}{|l|}{ Sulphur level } \\
\hline $\mathrm{S}_{0}(0 \mathrm{~kg} / \mathrm{ha})$ & 15.83 & 25.75 & 7.42 & 0.62 & 34.98 & 58.19 \\
\hline $\mathrm{S}_{1}(20 \mathrm{~kg} / \mathrm{ha})$ & 16.56 & 28.45 & 8.78 & 0.70 & 31.06 & 55.29 \\
\hline $\mathrm{S}_{2}(40 \mathrm{~kg} / \mathrm{ha})$ & 16.78 & 30.23 & 9.62 & 0.76 & 29.07 & 52.66 \\
\hline $\mathrm{S}_{3}(60 \mathrm{~kg} / \mathrm{ha})$ & 16.91 & 30.40 & 9.78 & 0.79 & 28.77 & 50.85 \\
\hline $\mathrm{SEm} \pm$ & 0.35 & 0.60 & 0.21 & 0.02 & 0.65 & 0.79 \\
\hline $\mathrm{CD}$ at $0.05 \%$ & 1.02 & 1.74 & 0.60 & 0.04 & 1.86 & 2.28 \\
\hline \multicolumn{7}{|l|}{ Spacing } \\
\hline $\mathrm{D}_{0}(30 \times 20 \mathrm{~cm})$ & 16.08 & 26.40 & 7.55 & 0.64 & 34.14 & 57.85 \\
\hline $\mathrm{D}_{1}(30 \times 30 \mathrm{~cm})$ & 16.30 & 28.23 & 8.92 & 0.69 & 31.43 & 55.31 \\
\hline $\mathrm{D}_{2}(45 \times 30 \mathrm{~cm})$ & 16.82 & 30.05 & 9.52 & 0.74 & 29.51 & 52.74 \\
\hline $\mathrm{D}_{3}(45 \times 45 \mathrm{~cm})$ & 16.88 & 30.16 & 9.62 & 0.77 & 28.81 & 51.09 \\
\hline $\mathrm{SEm} \pm$ & 0.35 & 0.60 & 0.21 & 0.02 & 0.65 & 0.79 \\
\hline $\mathrm{CD}$ at $0.05 \%$ & 1.02 & 1.74 & 0.60 & 0.05 & 1.86 & 2.28 \\
\hline
\end{tabular}


Table.2 Effect of sulphur and spacing on yield attributes and yield of knol-khol

\begin{tabular}{|c|c|c|c|c|c|c|}
\hline Treatments & Diameter of knob & Volume of knob & $\begin{array}{c}\text { Fresh weight of } \\
\text { leaves/plant }\end{array}$ & $\begin{array}{c}\text { Fresh weight of } \\
\text { knob/plant }\end{array}$ & Knob:leaf ratio & Total yield (q/ha) \\
\hline \multicolumn{7}{|l|}{ Sulphur level } \\
\hline$S_{0}(0$ kg/ha) & 6.27 & 98.80 & 70.35 & 72.71 & 0.97 & 156.70 \\
\hline$S_{1}(20 \mathrm{~kg} / \mathrm{ha})$ & 7.03 & 108.42 & 114.54 & 103.19 & 1.11 & 191.45 \\
\hline$S_{2}(40 \mathrm{~kg} / \mathrm{ha})$ & 7.45 & 113.13 & 147.58 & 126.31 & 1.17 & 216.63 \\
\hline$S_{3}(60 \mathrm{~kg} / \mathrm{ha})$ & 7.75 & 115.92 & 156.86 & 133.37 & 1.18 & 223.64 \\
\hline SEm \pm & 0.14 & 1.60 & 3.42 & 2.89 & 0.01 & 3.89 \\
\hline CD at $0.05 \%$ & 0.40 & 4.62 & 9.87 & 8.34 & 0.03 & 11.24 \\
\hline \multicolumn{7}{|l|}{ Spacing } \\
\hline$D_{0}(30 \times 20 \mathrm{~cm})$ & 6.48 & 100.35 & 81.01 & 77.68 & 1.03 & 194.21 \\
\hline$D_{1}(30 \times 30 \mathrm{~cm})$ & 6.97 & 108.23 & 113.05 & 101.46 & 1.10 & 219.16 \\
\hline$D_{2}(45 \times 30 \mathrm{~cm})$ & 7.38 & 112.99 & 143.20 & 124.78 & 1.14 & 209.60 \\
\hline$D_{3}(45 \times 45 \mathrm{~cm})$ & 7.67 & 114.71 & 152.08 & 131.66 & 1.15 & 165.45 \\
\hline SEm \pm & 0.14 & 1.60 & 3.42 & 2.89 & 0.01 & 3.89 \\
\hline CD at $0.05 \%$ & 0.40 & 4.62 & 9.87 & 8.34 & 0.03 & 11.24 \\
\hline
\end{tabular}

Table.3 Interactive effect of sulphur and spacing on diameter, volumeand yield of knob of knol-khol

\begin{tabular}{|c|c|c|c|c|c|c|c|c|c|c|c|c|}
\hline \multirow[t]{3}{*}{ Spacings } & \multicolumn{12}{|c|}{ Sulphur levels } \\
\hline & \multicolumn{4}{|c|}{ diameter of knob $(\mathrm{cm})$} & \multicolumn{4}{|c|}{ volume of knob (cc) } & \multicolumn{4}{|c|}{ Yield of knob $\left(q\right.$ ha $\left.^{-1}\right)$} \\
\hline & Control & $\begin{array}{c}20 \mathrm{~kg} / \\
\mathrm{ha}\end{array}$ & $\begin{array}{c}40 \mathrm{~kg} / \\
\mathrm{ha}\end{array}$ & $\begin{array}{c}60 \mathrm{~kg} / \\
\mathrm{ha}\end{array}$ & Control & $\begin{array}{c}20 \mathrm{~kg} / \\
\text { ha }\end{array}$ & $\begin{array}{c}40 \mathrm{~kg} / \\
\text { ha }\end{array}$ & $\begin{array}{c}60 \mathrm{~kg} / \\
\text { ha }\end{array}$ & Control & $\begin{array}{c}20 \mathrm{~kg} / \\
\text { ha }\end{array}$ & $\begin{array}{c}40 \mathrm{~kg} / \\
\mathrm{ha}\end{array}$ & $\begin{array}{c}60 \mathrm{~kg} / \\
\text { ha }\end{array}$ \\
\hline $30 \times 20 \mathrm{~cm}$ & 5.50 & 6.98 & 7.02 & 6.40 & 80.13 & 101.72 & 110.46 & 109.09 & 153.23 & 188.75 & 221.12 & 213.73 \\
\hline $30 \times 30 \mathrm{~cm}$ & 6.00 & 7.13 & 7.21 & 7.55 & 100.92 & 110.81 & 108.73 & 112.44 & 173.40 & 213.31 & 238.45 & 251.48 \\
\hline $45 \times 30 \mathrm{~cm}$ & 6.55 & 6.51 & 8.39 & 8.08 & 105.05 & 110.02 & 118.96 & 117.93 & 169.75 & 202.78 & 226.73 & 239.15 \\
\hline $45 \times 45 \mathrm{~cm}$ & 7.03 & 7.51 & 7.17 & 8.98 & 109.11 & 111.14 & 114.36 & 124.21 & 130.42 & 160.97 & 180.22 & 190.20 \\
\hline S.Em. \pm & 0.28 & & & & 3.20 & & & & 9.41 & & & \\
\hline C.D. $(P=0.05)$ & 0.80 & & & & 9.25 & & & & 27.17 & & & \\
\hline
\end{tabular}


Effect of spacing on yield and yield attributes

Data (Table 1) further revealed that levels of spacing also significantly influenced the diameter and volume of knob. Maximum diameter of knob $(7.70 \mathrm{~cm})$ and volume of knob $\left(\begin{array}{lll}114.71 & \mathrm{cc}\end{array}\right)$ was recorded in $\mathrm{D}_{3}$ treatment $(45 \times 45 \mathrm{~cm}$ spacing) while minimum $(6.48 \mathrm{~cm}$ and $100.35 \mathrm{cc})$ was recorded in $\mathrm{D}_{0}$ treatment (30x20 $\mathrm{cm}$ spacing). The spacing $45 \times 45 \mathrm{~cm}\left(\mathrm{D}_{3}\right)$ was found statistically at par with $45 \times 30 \mathrm{~cm}$ spacing $\left(\mathrm{D}_{2}\right)$ represented a significant increase of 18.36 and 10.04 per cent by diameter and 14.30 and 5.98 per cent by volume of knob over $30 \times 20 \mathrm{~cm}$ and 30x30 cm spacing, respectively.

Interactive effect of sulphur levels and spacing on diameter $(\mathrm{cm})$ and volume of knob (cc)

Data in Table 1 showed that the combined effects of different sulphur levels and spacing on diameter of knob were found to be significant. The application of $60 \mathrm{~kg}$ sulphur along with $45 \times 45 \mathrm{~cm}$ spacing recorded the maximum diameter of knob $(8.98 \mathrm{~cm})$ and volume of knob $(124.21 \mathrm{cc})$ per plant but in case of diameter it was found statistically at par with $40 \mathrm{~kg}$ sulphur per ha with $45 \times 30 \mathrm{~cm}$ spacing. The treatment combination of $40 \mathrm{~kg}$ sulphur with $45 \times 30 \mathrm{~cm}$ spacing registered an increase of 52.55 per cent in diameter of knob over control with $30 \times 20 \mathrm{~cm}$ spacing proved as good as $60 \mathrm{~kg}$ sulphur along with $45 \times 45 \mathrm{~cm}$ spacing and found significantly superior to rest of the treatment combinations. While, in case of volume of knob it was found statistically at par with $60 \mathrm{~kg}$ sulphur per ha with $45 \times 30 \mathrm{~cm}$ spacing and $40 \mathrm{~kg}$ sulphur per ha with $45 \times 30 \mathrm{~cm}$ spacing. The treatment combination of $40 \mathrm{~kg}$ sulphur with $45 \times 30 \mathrm{~cm}$ spacing proved as good as $60 \mathrm{~kg}$ sulphur along with $45 \times 45 \mathrm{~cm}$ spacing and $60 \mathrm{~kg}$ sulphur with $45 \times 30 \mathrm{~cm}$ spacing found significantly superior to rest of the treatment combinations. Application of $40 \mathrm{~kg}$ sulphur with $45 \times 30 \mathrm{~cm}$ spacing registered an increase of 48.46 per cent in diameter of knob over control with $30 \times 20 \mathrm{~cm}$ spacing.

A perusal of data (Table 2) revealed that applied levels of spacing significantly enhanced the fresh weight of leaves and knob per plant and knob: leaf ratio over 30x20 cm and $30 \times 30 \mathrm{~cm}$ spacing. The maximum fresh weight of leaves (152.08g) and knob (131.66 g) and knob: leaf ratio (1.15) was recorded in $45 \times 45 \mathrm{~cm}$ spacing whereas minimum was recorded in 30x20 cm spacing $(81.01,77.68 \mathrm{~g}$ and 1.03). However, spacing $45 \times 30 \mathrm{~cm}$ was found statically at par with $45 \times 45 \mathrm{~cm}$ spacing. The increase in fresh weight of leaves and knob and knob: leaf ratio under $45 \times 30 \mathrm{~cm}$ spacing was found to be 76.77, 26.67 and $60.63,22.98$ and 11.65 and 4.55 per cent over $30 \times 20 \mathrm{~cm}$ and $30 \times 30 \mathrm{~cm}$ spacing, respectively.

Data presented in Table 3 further reveal that total yield of knol-khol was significantly influenced by different spacing levels over $45 \times 45 \mathrm{~cm}$ spacing. The spacing $30 \times 30 \mathrm{~cm}$ was recorded significantly higher yield per hectare over $45 \times 45 \mathrm{~cm}$ and $30 \times 20 \mathrm{~cm}$ spacing which was found statistically at par with $45 \times 30 \mathrm{~cm}$ spacing. The mean increase in total yield per ha due to $45 \times 30 \mathrm{~cm}$ spacing over $45 \times 45 \mathrm{~cm}$ and $30 \times 20 \mathrm{~cm}$ spacing were 26.32 and 7.92 per cent, respectively. The combined or interaction effect of sulphur levels with spacings on total yield of knol-khol (per hectare) was found to be significant. Application of $60 \mathrm{~kg}$ sulphur with $30 \times 30 \mathrm{~cm}$ spacing gave highest total yield per hectare $(251.48 \mathrm{q})$ being at par with $60 \mathrm{~kg}$ sulphur with $45 \times 30 \mathrm{~cm}$ spacing and $40 \mathrm{~kg}$ sulphur with $30 \times 30 \mathrm{~cm}$ spacing. Application of $40 \mathrm{~kg}$ sulphur along with $30 \times 30 \mathrm{~cm}$ spacing registered an increase of 55.62 per cent in per hectare yield over control, respectively. 


\section{References}

Arnon, D.I. 1949. Copper enzymes in isolated chloroplast- polyphenol oxidase in Beta- vulgaris. Plant Physiol., 24: 1-15.

Bhagavatagoudra, K.H. and Rokhade, A.K. 2001. Effect of sources and levels of sulphur nutrition on growth and yield of cabbage. Karnataka J. Agri. Sci., 14(3): 724-726.

Bhangre, K.K., Sonawane, P.C. and Warade, S.D. 2011. Effect of different varieties and spacing on growth and yield parameters of broccoli (Brassica oleraceavar. Italica Plenck) under Pune conditions. Asian J. Horticulture, 6(1): 74-76.

Bijarnia, H.S. and Dixit, V.S. 1996. Growth and yield of cauliflower (Brassica oleracea var. botrytis L.) as affected by sulphur. Annals of Biol., 12(2): 232234.

Biswas, D.R., Ali, S.A. and Khera, M.S. 1995. Response of gobhisarson (Brassica napus L.) to $\mathrm{N}$ and S. J. Indian Society of Soil Sci., 43: 220-223.

Choudhary, B. 1967. Vegetable, National Book Trust of India. New Delhi.

Dev, H. 2012. Standardization of planting time and spacing in broccoli cv. Green Head for lower hills of Northern India. Int. J. Farm Sci., 2(1): 36-42.

Dhar, M., Jana, J.C. and Maity, T.K. 1999. Response of cabbage to sulphur fertilization, Veg. Sci., 26(1): 82-84.

Gautam, P. 2012. Response of knol-khol (Brassica oleraceavar. caulorapa) to organic manures and inorganic fertilizers. A M.Sc. (Ag.) Thesis submitted to S.K.R.A.U. Bikaner.

Goswami, N.N. 1988. Sulphur in Indian Agriculture. The Fertilizer Association, New Delhi, India.

Hara, J., Sugimoto, K. and Sonoda, Y. 1981. Nutritional relationship between nitrogen and sulphur in cabbage
(Brassica oleracea var. capitata). J. Japanese Soc. Horticulture. Sci., 50(1): 60-65.

Hossan, N. and Olsen, R.A. 1966. Influence of applied sulphur on availability of soil nutrients for corn (Zea mays L.) nutrition. Proc. Soil Sci. Society America, 30(2): 284-286.

Jamre, B.R., Nagaich, K.N. and Verma, H. 2010. Effect of different levels of sulphur and zinc on growth and yield of cauliflower (Brassica oleraceavar. botrytis L.). The Asian J. Horticulture, (2): 323-325

Kanwar, J.S. 1976. Soil fertility -Theory and practice, ICAR, New Delhi.

Khan, B.A., Shilling, P.G., Brusewitz, G.H and McNew, R.W. 1991. Force to shear the stalk, stalk diameter and yield of broccoli in response to nitrogen fertilization and within row spacing. $J$. American Society of Horticultural Sci., 116(2): 222-227.

Khatun, K., Saha, S.R. and Mostarin, T. 2011. Growth and yield of broccoli as influenced by plant spacing. Int. $J$. Sustainable Agri. Technol., 7(12): 7-12.

Moniruzzaman, M. 2011. Effect of plant spacings on the performance of hybrid cabbage (Brassica oleracea var. capitata) varieties. Bangladesh J. Agri. Res., 36(3): 495-506.

Patil, B.N., Ingle, V.G. and Patil, S.S. 2003. Effect of spacings and nitrogen levels on growth and yield of knol-khol (Brassica oleraceavar. caulorapa) $c v$. White Vienna, Annals of Plant Physiol., 7(2): 110-113.

Prasad, P.H., Thapa. U., Mandal, A.R. and Vishwakarma, R. 2010. Response of varieties, spacing and aphid management on growth and yield of sprouting broccoli (Brassica oleraceavaritalica L.) under West Bengal condition. Environ. Ecol., 28(2): 779-782. 
Rai, N., Patel, R.K. and Dongra, R. 2003. Effect of various spacings and fertilizer combinations on growth and yield of Knol-Kholcv. White Vienna. Agri. Sci. Digest, 23(1): 41-43.

Shekhawat, H.S. 1992. Effect of sources and levels of sulphur on growth and yield of cauliflower (Brassica oleraceavar. botrytis L.). A Thesis of M.Sc. (Ag.) submitted to RAU, Bikaner.

Singh, S.P. 1989. Production technology of vegetable crops. Agri. Res. Communication Centre, Karnal (Haryana).

Talukder, M.R., Banu, M.B., Hoque, A.K.M.S. and Hoque, M.A. 2013. Response of knolkhol to different levels of nutrients. Ecofriendly Agri. J., 6(2): 29-33.

Tandon, H.L.S. $1986 . \quad$ Fertilizer recommendation for horticultural crops in India, A Guide Book F.D. Co., New Delhi, pp. 112.

Thirupal, D., Madhumathi, C. and Syam Sundar Reddy, P. 2014. Effect of planting dates and plant spacings on growth, yield and quality of broccoli under Rayalaseema zone of Andhra Pradesh, India. Plant Arch., 14(2): 1095-1098.

Yadav, B.R. and Paliwal, K.V. 1990. Response of cauliflower to nitrogen and fertilization in saline water stress. Veg. Sci., 17: 1-6.

\section{How to cite this article:}

Bairwa, R.K., S.P. Singh, A.K. Mahawar and Kishore Kumar Das. 2017. Influence of Sulphur and Spacing on Growth and Yield Attributes of Knol-Khol (Brassica oleracea Var. Gongylodes L.) Var. Early White Viana. Int.J.Curr.Microbiol.App.Sci. 6(5): 2438-2447. doi: https://doi.org/10.20546/ijcmas.2017.605.273 